\title{
TRANSSEXUALITY IN IRAN: ISSUES AND CHALLENGES
}

\author{
Zahra Sarcheshmehpour \\ PhD Student, Department of Shariah and Law, \\ Academy of Islamic Studies, \\ University of Malaya, Kuala Lumpur. \\ zsarcheshmehpoor@yahoo.com \\ Raihanah Abdullah \\ Professor, Department of Shariah and Law, \\ Academy of Islamic Studies, \\ University of Malaya, 50603 Kuala Lumpur. \\ raihanah@um.edu.my
}

\begin{abstract}
Iran like many countries of the world, has recorded growth in the cases of transsexuals. Being an Islamic nation, issues of transsexuality could be controversial in view of the fact that it is perceived as a leeway for homosexuality. Transsexuality is permissible, while, homosexuality is a crime punishable by death in Iran. This is in view of the fact that transsexuality is perceived as a form of disability that can be cured through medical treatment. This paper intends to examine the position of gender, transsexuality and sex reassignment surgery in Iran. Doctrinal methodology was used in arriving at the findings of the research. According to the findings, Sex reassignment surgery is the most medically effective treatments for gender identity disorders. It increases satisfaction and the quality of transsexuals' life after surgery in compare with responding before surgery and Iran is ranked second in cases of sex change surgeries globally. Despite, the legality of sex reassignment surgery and change personal documents, transsexuals face challenges in other aspects of life in Iran like other countries.
\end{abstract}

Keywords: Iran, transsexuality, sex reassignment surgery, homosexuality, Islam 


\section{INTRODUCTION}

Transsexuality as a medical, psychological, and socio-cultural phenomenon has been discussed in a number of science forums in the last century. It has been diagnosed as a gender identity disorder by early German sexologists and psychiatrists such as Richard Von Kraft Ebbing (1840-1902), Magnus Hirschfield (1868- 1935), John Money, and Harry Benjamin (1885-1986) (Stephen W. 2010, 4-5). Based on Euro-American studies, the term "transsexual" is used to refer to individuals who have a strong sense of their biological and physiological sex and do not believe that their gender identity corresponds to the sex they were assigned at birth - especially those who have the intention to reassign sex surgically or undergo hormone therapy (Shapiro 2008, 138-161). This caused some of the individuals to change their sex by sex reassignment surgery to make their biological or physiological sex conform to their gender identity. Transsexuals are not homosexuals, although, unfortunately, they are often assumed as homosexuals and rejected by many people ${ }^{1}$. Sex reassignment surgery is a medical treatment accepted by Harry Benjamin International Gender Dysphoria Association for gender identity disorders (Shapiro 2008: 138). As with Medical science and surgical technological developments, today's doctors are able to remove the wrong genitals in the body and replace the symptoms and signs of the opposite sex, to create congruence between physical sex and gender identity (Haneef 2011: 98-107).

The male and female genders are the globally accepted types of gender, any attempt to introduce another form of gender or identity outside this will always be viewed with caution. In fact, the attempt to identify transsexuals as individuals suffering from gender identity disorder that can be cured through sex reassignment surgery has resulted in hot debate across the Muslim world. Iran has become the global hub of transsexuals (TS) and Sex Re-assignment Surgeries (SRS) in recent times. Transsexuality has recognized as a gender identity disorder and sex reassignment surgery as the best medical treatment for transsexuals has allowed under the Islamic law. In fact SRS is considered as a right as health, marriage, employment and education.

Surprisingly, there is widespread media propaganda that permission of sex reassignment surgery in Iran is for the eradication of homosexuality (Bucar, Elizabeth M. Shirazi, Faegheh, 2012: 421). This paper examines the legal and socio-political status of TS in Iran. The discussion of the Iranian status on SRS and TR goes a long way in demonstrating the universality and the positive

$\overline{1}$ Mir Jalali. B, Paris-trained surgeon and Iran's leading specialist in sex-change surgery. 
impact of Islamic Law and Sharia on proffering panacea for modern human challenges.

\section{THE POLITICS OF GENDER IN IRAN}

Iran or Persia is an Islamic country in Western Asia with predominantly Shia population. The constitution in Iran is governed by Islamic principles. The legal system in the country is based on Islamic jurisprudence and like other Islamic countries; it is mandated to respect the Shariah in all economic, cultural and social structures. Although the Western Media has depicted a negative image of gender intolerance in Iran (Najmabadi Afsaneh, 2005: 54-77), this gender dichotomy has been in existence in all Islamic societies and it is observable in all social structures as the deep extreme form of this gender boundary had been in medievalist Islamic societies (Sanders Paula, 1991: 74).

This difference in gender identity under Islamic law is born out of the belief that every gender has a peculiar role, social standing and expectations. This dichotomy is not gender discrimination. It is the different of role and performance of every gender in the society. Indeed, it does not mean that men and women are unequal in sight of Allah. The Qur' $\bar{a} n$ is explicit to the effect that men and women have equal rights and obligations. ${ }^{2}$

The permission of sex reassignment surgery in Iran has allowed the western media to give contradictory information about Iran from formal and informal forums and websites, occasionally some exotic reports are heard such as; "More Iranian changing their sex", 3 "Critical Montages: Changing Sex, Changing Islam!" " Sex change is forcible operation in Iran. They argued that permission of Sex reassignment surgery in Iran is done only to eradicate homosexuality"5 and the Iranian authorities recognized sex reassignment surgeries to demonstration their position on sexual liberty and so on.

2 Ali, Yusuf, trans. (2010). "The Qur'an: Translation". 26th US edition, ed. S. Smith. New York. Qur'ān, Yusuf Ali, 4:124, 33:35, 49:13

3 Fathi Nazila (2004). "As Repression Eases, More Iranians Change Their Sex." New York Times, http://www.nytimes.com/2004/08/02/world/as-repression-easesmore-iranians-change-theirsex.

4 "Changing Sex, Changing Islam," http://montages.blogspot.com/2004/08/ changing-sex-changing-islam.html

5 Robert Tait (2007). "Sex Change Funding Undermines No Gays Claim.” Guardian. Online: http://www.guardian.co.uk/world/2007/sep/26/iran.gender; Robert Tait (2005). "A Fatwa for Freedom," The Guardian World News section, http://www. guardian.co.uk/world/2005/jul/27/gayrights.iran. 
The central issue in this research is on the possibility of simultaneously operating two opposite positions about gender in Iran; while the homosexuality is extremely forbidden and homosexuals are punished by death penalty, transsexuality is permissible and transsexuals are allowed to undergo sex reassignment surgery and change all identification documents according to their new sex (Bucar. Elizabeth M. Shirazi, Faegheh, 2012: 419).

Homosexuality and transsexuality are two entirely distinct issues. Transsexuality is an inherent biological defect and transsexuals are patient with gender identity disorder treatable by medical surgery and hormone therapy (Shapiro Judith, 2008: 138), while homosexuality as a sexual intercourse between two persons of the same sex and it is a sinful sexual behavior.

In contrast of homosexuality, transsexuality has not been categorically prohibited by Shariah, Homosexuality is clearly condemned by the Qur'ān and Sunnah, and the Prophet Muhammad explicitly scorns any same sex and sexual activities between two same sex persons.

\section{HOMOSEXUALITY IN IRAN}

Homosexuality has become popular around the world due to its legalization by some countries and same sex marriage is on the rise (Ibid). Homosexuality and sexual relation between persons of the same sex is not only sinful and illegal according to Islamic law, but it is also considered a punishable crime. Homosexuality has always been considered as a deviant behavior in Islamic societies because it is against religious principle. It is classified as crimes with severe punishment in most Islamic countries.

Sexual intercourse between males is called Lavat in Persian language and "Liwat" in Arabic language and in the legal and jurisprudential texts. In the modern time they called as Gay, while same sex activities between females is called Sihagh or Mosaheqeh, and in the modern time is called Lesbianism (Symons, Donald, 1979: 309-314).

Since, the legal system of Iran is according to the Islamic law and the law in Iran is extracted from Islamic Jurisprudence, homosexuality is prohibited under Iranian Islamic Law. According to Iranian Penal Code, all sexual relations between persons of the same sex are subjected to punishment which is fixed in Shariah or Islamic Law. Both the Holy Qur'ān and Sunnah prohibit homosexuality and condemn any coerced and consensual sexual intercourse between same sex of men and women. 
The condemnation of homosexuality in Iran been criticized by some media houses, Human Right Organizations and authors outside Iran. They compared the status of homosexuals with transsexuals. The prohibition of sodomy and all forms of same sex activities is based on the explicit rule of Shariah. There are some clear references about the condemnation of homosexuality in the Qur'ān:

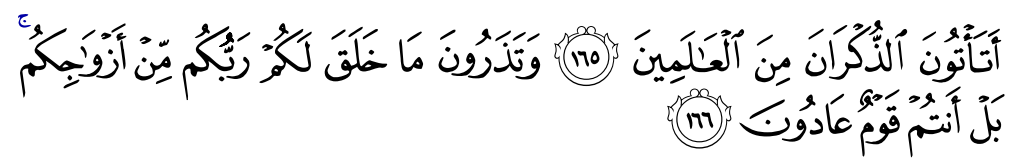

"What! Do you come to the males from among the creatures, and leave what your lord has created for you of your wives? Nay, you are a people exceeding limits"

(Surah al-Shu'arā', 26: 165-166)

The Qur'ān states further:

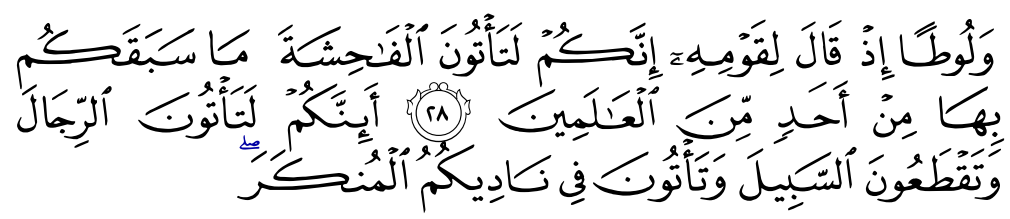

"And (we sent) Lut when he said to his people: most surely you are guilty of an indecency which none of the nations has ever done before you; what! Do you come to the males and commit robbery on the highway, and you commit evil deeds in your assemblies?"

(Surah al-'Ankabūt, 29: 28-29)

The two main references are related to the story of Lūt (Lot):

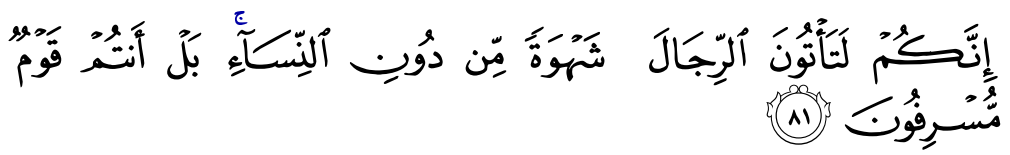

"Most surely you come to males in lust besides females"

(Surah al-A'rāf, 7: 81)

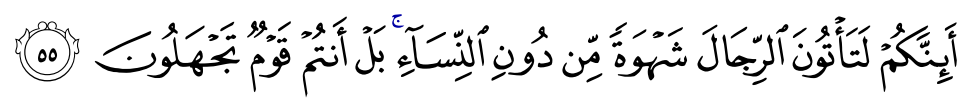

"What! Do you indeed approach men lustfully rather than women?"

(Surah al-Naml, 27: 55) 
On lesbianism, the verse 15 of Surah al-Nisā' provides the legal punishment for same sex behavior between females thus:

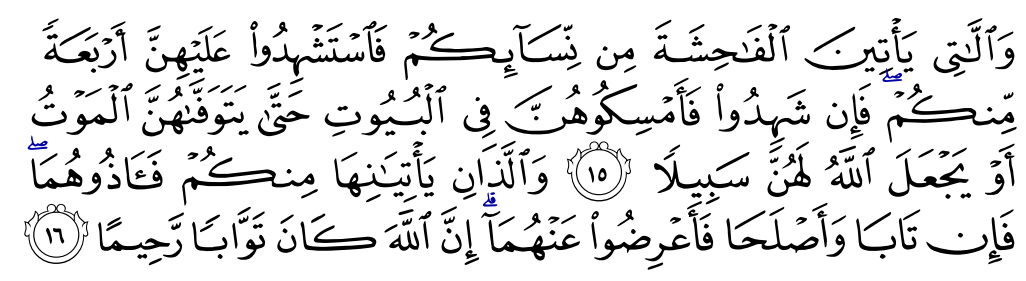

"If any of your women are guilty of lewdness, take the evidence of four (reliable) witnesses from amongst you against them; and if they testify, confine them to houses until death does claim them, or Allah ordain for them some (other) way. If two men among you are guilty of lewdness, punish them both. If they repent and amend, leave them alone; for Allah is Oft-returning, most Merciful"

(Surah al-Nisā', 4: 15-16)

There are two hadiths that is attributed to Prophet about punishment for homosexuality as the first hadìth is narrated by 'Abd Allāh Ibn 'Abbas that Prophet SAW said:

"If you find anybody committing the act of the People of Lut i.e. sodomy, then kill the one doing it and the one with whom it is done." 6

And the second hadith that is narrated about committing sodomy on the authority of Abu Hurayrah from Prophet SAW said:

"Stone the upper and the lower (i.e. both persons committing it). " 7

The following two ahadith are clear on the description and chastisement of or sodomy (Simon Rita James, Brooks Alison: 2009):

"When a man mounts another man, the throne of God shakes."

"Kill the one that is doing it and also kill the one that it is being done to."

There are various opinions among different schools of thought about the punishment of homosexuality, the prominent Islamic jurist Yusuf al-Qaradawi (2001) opined:

6 This hadīth is recorded by At-Tirmidhi (1:152), Al-Bukhari. An-Nisaei. AbuDawud (4462) Imam Ahmad. and Ibn Hazm.

7 This hadīth is recorded by al-Bukhari, al-Tirmidhi, Ibn Majah and Ibn Hazm. 
"The jurists of Islam have held different opinions concerning the punishment for this abominable practice. Should it be the same as the punishment for zina, or should both the active and passive participants be put to death? While such punishments may seem cruel, they have been suggested to maintain the purity of the Islamic society and to keep it clean of perverted elements. " (A1Qardawi 1997, Rehman \& Polymenopoulou, 2012)

In Hanafi school of thought, same sex intercourse is not considered as adultery and according to most Hanafi scholars, they are not punishable by death and it will be left for the judge to exercise his discretion. Some Hanafi Jurists allowed punishment by death. ${ }^{8}$ In the opinion of the Maliki School, any same sex intercourse should be punished as adultery and hence punishable by death. Ibn Shihab replied to Malik's question about committing sodomy thus: it is punishable by death through stoning, whether or not he is legally married. ${ }^{9}$

The Shāfi ${ }^{1} \bar{i}$ school of thought has differentiated between married and unmarried persons. Married person found guilty of homosexuality would be punished to death by stoning, while unmarried person is to be punished by flogging. The Ja' fari Shia School opined that any same sex intercourse between married and unmarried persons is punishable in the same way as adultery. Seyyed al-Khoi says committing same sex intercourse, married or unmarried, is punishable by death as adultery (Ibid). All the Schools of thought require four witnesses to witness the actual act before the offence can be established in both sodomies as well for adultery (Bello, Shafi'i: 2012). In most Islamic nations, same sex activities are punished by death; they include Iran, Saudi Arabia, Sudan, Mauritania and Yemen (Rehman \& Polymenopoulou, 2012: 4).

Sex and sexual activities are a part of human nature and is sanctioned by Islam; these activities should be done according to the limits set by Allah and within marriage. In addition, the prohibition and punishment of homosexuality is not only a part of Iranian sexual rights and politics but that extends to most Islamic countries like Saudi Arabia, Sudan, Afghanistan, Nigeria, United Arab Emirates, Pakistan, Mauritania and Yemen (Bucar, Elizabeth M. Shirazi, Faegheh, 2012: 427). Although the death penalty for sodomy is not specifically addressed by Qur'ann, the punishment of death for same sex acts was derived through interpretation of the Qur'ān, hadìth and qiyās (Ibid).

\footnotetext{
$8 \mathrm{http}: / / \mathrm{www}$. religionfacts.com/homosexuality/islam.htm

9 Ibid 24. Malik Ibn Ana's. Al-Muwatta, Aisha Bewley. Inverness Scotland: Medina Press1. 1989. 346.
} 
Any sexual intercourse outside of traditional marriage is criminalized under Iranian Law. In the Iranian Penal Code sexual intercourse between males is defined as Sodomy ${ }^{10}$ and same sex activities between females with genital contact is defined as Lesbianism or Mosaheqeh in Persian language. ${ }^{11}$ Articles 108-126 of Iranian Penal Code are related to punishment for Sodomy and articles 127-134 are about punishment for lesbianism. Both males and females are punishable if they are of sound mind, mature and consenting parties. Although the punishment for both sodomy and lesbianism is left for the Shariah Judge, but the maximum punishment for sodomy and adultery is death. ${ }^{12}$ Punishments for same sex activities between females attract different forms of punishment. For first three times, each lesbian will be punished with 100 lashes if it is proven in court through testimony of four witnesses ${ }^{13}$ and for the fourth time, they will be punished by death if found guilty. ${ }^{14}$

Further, even foreplay or any non-penetrative sexual activities between males is punishable by hundred lashes. ${ }^{15}$ The Penal Code states further that "if two men who are not related by blood lie naked under the same cover without any necessity" they will punished by ninety nine lashes ${ }^{16}$ and also if two unrelated women lie under one cover without necessity, they will be punished by less than 100 lashes. ${ }^{17}$ It should be noted that in both sodomy and lesbianism the testimony of four men is required to proof the crime. ${ }^{18}$ These punishments do not target only homosexuals, it is applicable to all same sex conducts regardless of whether or not they identify themselves as gay, heterosexual, bisexual or transgender or they are members of sexual minorities.

\section{TRANSSEXUALITY IN IRAN}

Transsexuality has been recognized as a gender identity disorder in Iran and transsexuals have been classified as patients with sexual abnormality. In a Fatwa in 1963, Imam Khomeini opined that sex reassignment surgery is a medical treatment for transsexuals and is allowed under Islamic law (Khomeini,

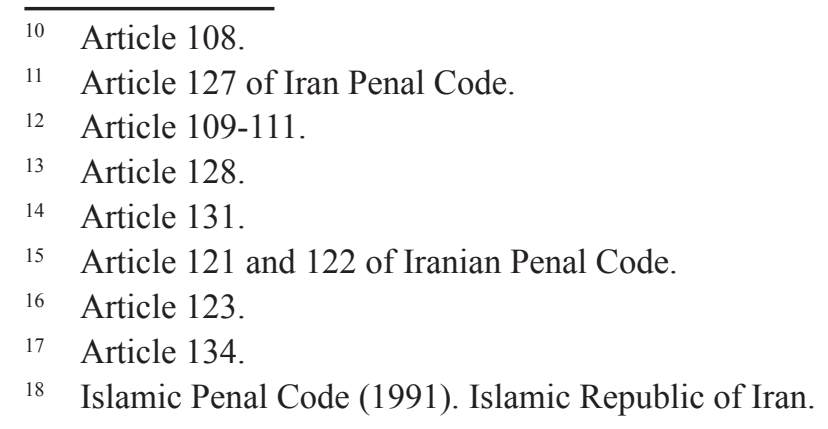


Ruhullah, 2000: 596-598). After Khomeini's fatwa, Transsexualism has supported by Iranian authorities and government.

Iran has become a popular home for sex reassignment surgeries and is a global leader for sex change due to its recognition of transsexuality and permission of sex reassignment surgery. It has the best medical and social services for transsexuals and carries out more operations in the world after Thailand (Raha Bahreini: 2012), According to Dr. Bahram Mirjalali, ${ }^{19}$ Iran is a paradise for transsexuals (David Graham: 2010).

Sex change operation for transsexuals is now considered as a human right in Iran just like other rights such as rights to marriage, health, employment, education etc. (Javaheri, Fatemeh, 2010: 368). Transsexual individuals have right to change their sex for treatment but that must be under trustworthy physicians and according to international standards. ${ }^{20}$ They can also change the name and all identification documents even birth certificates. The procedure of sex transition and the process of change of documents are performed under the government's supervision.

Unfortunately, the legalization of transsexuality and recognition of sex reassignment surgery as a treatment for transsexuals has led to some controversial opinions and criticisms outside Iran not withstanding its acceptance in most western and eastern countries. In response to these debates, it is necessary to examine the historical development of transsexuality in Iran.

\section{The History of Sex Reassignment Surgery in Iran}

The controversial history of sex reassignment surgery in Iran is usually traced to the 1979 revolution of Islamic Republic of Iran, ample evidence indicate that sex change operation is not new in Iran and these surgeries have been performed long before that in Iran. The first documented sex reassignment surgery performed in Iran by doctor Khalatbari in 1930. He changed an 18 years old young boy to a girl, by sex reassignment surgery; this surgery became a hotly debated issue (Coggon, Hammond et al., 2008: 4-17).

Before that, the sex change operations had been performed in hermaphrodites to discover and reveal the real sex or remove the weak sex singe to reinforce

19 An Iranian trained French physician that has done several sex reassignment surgery operations in Iran.

20 World Professional Association for Transgender Health (WPATH), available at: http://www.wpath.org/ 
the strong sex singe, as, the primary discussions about medical treatment for hermaphrodites and people with ambiguous sex and gender have been discussed by the Islamic scholars and prominent Islamic thinkers like Zakariya Al Razi and Ibn Sina (Sanders Paula, 1991: 76).

The 1940s saw the beginning of discussions on Transsexualism in Iran through some popular write-ups translated in Persian language as sex, love, marriage, sex change, homosexuality and gender misidentification. The conditions of genital alterion by surgery appeared in Iran in the early 1930s and these surgeries increased in the 1940s and 1950s. The concepts of sex and gender, gender determination and gender disorder appeared in Iranian medical literature via medical and psychological books in the late 1960s (Najmabadi Afsaneh, 2008: 37, 38).

By the 1970s there were more discussions on sex change surgery. Two hospitals in Tehran and Shiraz undertook sex reassignment surgeries according to a report by Kayhan on $11^{\text {th }}$ October 1976. Further, 20 persons out of fifty applicants for sex transition also underwent sex reassignment surgery (Najmabadi Afsaneh, 2012: 533-556).

The medical ethics of sex reassignment surgery was made subject of discussions by the professional organization of physicians known as the Medical Association of Iran and this organization pronounced that sex reassignment surgery is ethically acceptable in intersex individuals not more.

The political influence and power of Imam Khomeini made the issue of sex reassignment statutorily accepted in Iran following his fatwa in 1967 in Arabic language and reissuing the fatwa on 1985 in Persian language legalizing sex reassignment surgery. Sex reassignment surgery has been officially and legally allowed for transsexuals after the revolution of 1979 in Iran. Khomeini pronounced a Fatwa in 1983 that:

"There is no religious restriction on sex reassignment surgery as a treatment for transsexuals..." (Khomeini, 2000: 596- 97)

After Khomeini the validity of this medical remedy is supported by many influential jurists and Iranian authorities. By establishment of Islamic republic of Iran in the 1980, the conditions of transsexuality gained a new support financially and legally.

Islamic literatures classified humankind into male or female, however, hermaphrodite individuals whose gender is difficult to determine is equally accepted. With the advancement of modern science, the true identity of the hermaphrodites will be easily determined with accuracy. 
The Iranian media made a detailed coverage of the issue of transsexuals and sex change surgeries during the first three decades of the legalization of sex reassignment surgeries in Iran (Fahti, 2004; McDowall \& Khan, 2004; Eqbali, 2004; Tait, 2005; Harrison, 2005; Stack, 2005). Today, Iran has become prominent for sex reassignment surgery in the world and it is known as global leader for sex change operation according to Gordian (Coggon, Hammond et al., 2008: 4-17). It is one of few Islamic countries in the world that made sex change legal and allowed transsexuals to change all identification documents including birth certificates (Bahreini, 2012).

After the revolution of Islamic Republic of Iran, transsexuality is recognized as a disorder treatable by medical surgery and sex reassignment surgery is considered as a human right like marriage, education, health and etc. Today, Iran has access to a prominent position on acceptance transsexuality and permissible sex reassignment surgery as it has the best medical and social services for transsexuals in worldwide.

As many western media are report, over the past decades, Iran carried out more sex change operation than other countries except Thailand (Robert Tait: 2007). Between 1987 to 2001, 270 people applied for sex reassignment surgery, only 70 of them was female that submitted for change to male and 214 of were approved (Najmabadi Afsaneh, 2006: 3).

There were no formal statistics of transsexuals in Iran and indeed worldwide. As a common statistic there are approximately four to six persons in every 100,000 as transsexual. Approximately, 28,000 to 48,000 people are presumed to be transgender patients in Iran ((Kariminia Muhammad, 2010: 28 ). The male to female procedures are approximately $74 \%$ and the female to male procedure are 26\% (Kariminia Muhammad, 2010: 88, Bucar Elizabeth M. Shirazi, Faegheh, 2012: 419). This indicates that the percentage from males to female is higher than that of females to male. Recently, medical studies estimate that there are millions intersex individuals with ambiguous biological factors in the United States (Anne Fausto-Sterling, 1993: 255-286).

\section{The Legal Status of Transsexuality and SRS in Iran}

Iran is an Islamic Republic and operates an Islamic system of government based on Islamic principles. Due to its Islamic nature, Muslim scholars play significant role in determining the manner the Iranian government operates. The legality of transsexuality in Iran today is due to its approval by Imam Khomeini after the Iranian Islamic revolution of 1979. The legal status of transsexuality is that; transsexuals have been classified as people with gender 
identity disorder which is treatable by surgical remedy and Sex reassignment surgery has been recognized as an effective treatment for them and it is allowed under Islamic law and transsexuals can undergo the sex change as a matter of right (Najmabadi, Afsaneh, 2008: 8).

Unlike most countries in the Islamic world, sex reassignment surgery is legal in Iran and Iran also has become a home for European and Arab patients seeking to change their gender. Now the central question is that, who can be patient for Transsexuality and how can they seek for the permission for sex reassignment surgery? And can they change their identification documents and birth certificate?

Although surgical treatment has been allowed for intersexual by medievalists' prominent Islamic thinkers (Paula Sanders, 1991: 75, 88), Imam Khomeini passed the first fatwa to endorse sex reassignment surgery as a remedy for transsexuals in modern time. After Imam Khomeini's fatwa, sex reassignment surgery was supported by many influential Ayatollahs and Shia clerks in Iran. Thus, transsexuality has been allowed by Iranian authorities and sex reassignment surgery as a medical treatment is sanctioned by the Iranian authorities. Now transsexuals in Iran can undergo sex reassignment surgery and change legally their sex and obtain their new gender identification document.

It should be noted that the process of sex reassignment surgery includes the requirement that a psychiatric must diagnose the patient and recommend the operation. Similarly, the surgery must by in accordance with the World Professional Association for Transgender Health (WPATH). Furthermore, applicants, physicians and authorities in all stages are obliged to abide by Sharia and all operations performed under the government's supervision.

From 2000, three organizations have taken responsible for the affairs of all Iranian and non-Iranian transsexuals in Iran; the Legal Medical Organization, the Welfare organization and the Imam Khomeini Relief Committee work hand in hand towards running the affairs of transsexuals (Javaheri, Fatemeh, 2010: 368). The study of transsexuals' life and consulting to them and their families for encounter with potential problems is take responsibility to the Welfare Organization. The Legal Medical Organization is the most important and specialized center for psychological and medical examinations in Iran. They diagnose the real transsexuals from others and confirm whether these patients need hormonal and surgical treatment.

The examination process on patients may take a period of six month to two years. Since the private and Governmental bodies do not cover sex reassignment surgery cost, the Imam Khomeini Relief Committee is the third 
Organization that supports with some financial assistance to some patient that cannot afford the cost of surgery. These financial supports are done in the form of loan by Imam Khomeini Charity Foundation (Javaheri, Fatemeh, 2010: 369).

According to Article 33, No.8, of Examination and Medical Exemptions Regulations of Iran, transgender and MSM individuals are exemption from military service even though Military service is compulsory for all Iranian men who reach the age of 18. Based on this Article Iranian transgender will be classified as people with hormonal imbalance and they will are classified as people with Behavioral Disorder on their Military Exemption Cards. ${ }^{21}$

In the early of 2010, The General Director of the office for Socially Harmed at The Welfare Organization of Iran announced that the code for Military service exemption for transsexuals would be change. After 2 years of discussions and research with Military Service Organization, they concluded that Transsexuals would receive their exemption card under the glandular disorder clause based on Section 30 instead of the mental disorder clause according to Section 33.8. This is considered as an important step towards addressing the issue of transsexuals because they are often marked as people suffering from mental disorder due to Section 33.8 and suffer discrimination in employment, housing and education. Unlike section 30, that considered transsexuality as glandular disease hence allowing the transsexuals to enjoy the primary rights easily (Najmabadi Afsaneh, 2011: 533).

\section{The Legal Process and the Medical Procedure for Verification of Transsexuality}

It seems that, the legality of transsexuality in Iran has led to the misunderstanding that anyone in Iran can change his sex and gender at will, but this is not true. Sex reassignment surgery is not a cosmetic or elective operation, but a medical necessity. ${ }^{22}$ It is dependent on the individual's need and must be distinguished from case to case (Raha Bahreini, 2008: 27). Proving Transsexualism and obtaining the legal permission for sex reassignment surgery is only available

21 Director of Socially Vulnerable groups at the State Agency for National Well-Being, BBC Persian, January 6, 2010, http://www.bbc.co.uk/persian/ iran/2010/01/100106_107_transsexual_iran_sarbazi_armyexempton.shtml, accessed on 23 August 2010.

22 World Professional Association for Transgender Health. Standards of Care for Gender Identity Disorders. Sixth Version (February 2001). Available at: http:// www.wpath.org/documents2/socv6.pdf. 
to those who suffer from a strong gender identity disorder. They need to proof legally and medically that they suffer gender identity disorder and should be determined by medical and as well as religious experts (Bucar Elizabeth $\mathrm{M}$. Shirazi, Faegheh, 2012: 420).

It takes a period of six months for the experts to establish and separate between the real transsexuals from other sexual groups like homosexuals, hermaphrodites and other psychological disorders relating to sexual abnormalities.

Similarly, individuals diagnosed with Gender Identity Disorder must pass through three cycles of treatment: experience of a real life role of the new gender, hormone therapy of the desired sex and sex reassignment surgery will change the external appearance of the body and genitalia of the patient. These stages of treatment have been emphasized by Standards of Care for Gender Identity Disorder (Ibid).

After 6 months of psychology tests, the applicants must obtains a referral letter from a trustworthy psychologist to a court. After a private session by a court officer with the applicant, the patient will be referred to the Psychiatric Ward of the Legal Medicine Organization of Iran. This Ward is comprised of clinical psychologist and psychiatrists that are responsible for the final decision for sex reassignment surgery for the applicants. The DSM-IV diagnostic criteria will be used for the accurate diagnostic criteria of gender identity disorder and one or more of the MCMI-II, MMPI and Beck tests be used for psychiatric evaluation by Legal Medical Organization of Iran (Aghabikloo A, et al. 2012: 130).

They will do all medical and psychological tests including hormonal and chromosomal tests, ultrasound, radiology and physical examination. The applicants will be subjected to psychotherapy by a commission of psychiatrists at the Tehran Psychiatric Institute (TPI) approximately twelve sessions. This commission is responsible for reviewing the validity and legitimacy of the request for sex reassignment surgery, and finally makes recommendation to the Legal Medicine Organization of Iran for rejection or approval (Aghabikloo A, et al. 2012: 130).

The Commission recommends them to the psychiatric ward of Legal Medical organization of Iran for sex reassignment surgery. This Ward is responsible for the final decision and recommendation for operation is made as follows:

"The confirmation of affliction with gender identity disorders and 
cannot tolerate their biologic identity as a result of this affliction" (Ibid).

This certification allowed the applicant to follow the process of hormone therapy and sex reassignment surgery and the military service exemption. The procedure of hormone therapy and sex reassignment surgery may take place between six months to two years. This period is sensitive and the patients require special care and proper supervision. Due to the push for hormone therapy, some patients can go extra-length to administer the hormone to themselves without medical supervision and which will negatively affect the health of the patients.

In Iran it is not allowed for the applicants to behave, dress and live as a member of the opposite sex until the complete process of hormone therapy and sex reassignment surgery procedure has been completed. After agreement with sex reassignment surgery by legal Medical Organization' authorization, transsexuals can changed birth certificates with new identify (Aghabikloo A, et al. 2012: 133).

Changing the applicant's name and changing all new identification documents requires court order and that the order is according to the commission's certification. The post-operation transsexuals have to show their body to the court that has been changed to the opposite sex by sex reassignment surgery and hormone therapy. The new social role of transsexuals can take place after changing their name and birth documents.

\section{CONCLUSION}

The paper examined transsexuality in the Islamic Republic of Iran. It examined the historic am antecedents of transsexuality in Iran. It examined socio-cultural, legal and jurisprudential aspects of transsexuality. Since the constitution in Iran is governed by Islamic republic and the legal system in the country is based on Islamic principles, it is mandatory to respect Shariah principles in all economic, cultural and social structures. Transsexuality is different from homosexuality. Transsexuality is an inherent and biological defect treatable by medical surgery and hormone therapy, while homosexuality is a sinful sexual behavior and Homosexuals behave out of normal sexual bounds and commit sexual wrong.

The paper finds that transsexuality, as a gender identity disorder is accepted and accorded protection as of right by the legal system of Iran and Sex reassignment surgery has been recognized as an effective treatment for them. The sex reassignment surgery is not considered an attempt to change Allah's creation according to Islamic jurisprudence of Iran. The history of permitting 
transsexuality is traced back to prominent Islamic thinkers of Iran like Zakariya Al Razi and Ibn Sina. With the establishment of the Islamic Republic of Iran, and especially with Imam Khomeini's Fatwa on sex change, sex reassignment surgery became legally permissible after certain medical, psychological and religious conditions have been satisfied.

Unlike most Islamic countries, sex reassignment surgery is legal in Iran. Before the surgery is done, there is the requirement of psychiatric diagnosis and surgery must be done according to the World Professional Association for Transgender Health (WPATH). After the sex reassignment surgery, transsexuals are allowed to change all identification documents. Furthermore, three organizations have taken responsibility for transsexuals' affairs in Iran; the Legal Medical Organization, the Welfare organization and the Imam Khomeini Relief Committee. Most religious and jurisprudential issues are provided by Imam Khomeini and some Islamic scholars

On the whole, this paper finds that, SRS decrease the quality of transsexuals' life and the average of gender identity disorder after surgery is much less than before surgery. It creates serious compatibility between their mined and sexual organs and the psychological comfort will be improved. The findings also show that, since gender identity disorder effects a negative impact on intellectual and mental aspects of the quality of the life, other aspects of transsexuals' life is not influence with gender identity disorder. So, after sex reassignment surgery, transsexuals sometimes suffer from rejection and discrimination even within their own family, friends and in the wider societies. Public awareness on the fact that transsexuals suffer from a gender identity disorder and are different homosexuals will improve the perspective of the society on transsexuals.

\section{REFERENCES}

Abdullah Yusuf Ali (2008). Translation of the Qur'an. World Islamic Call Society.

Aghabikloo A, Bahrami M, Saberi SM, Emamhadi MA (2012). "Gender Identity Disorders in Iran; Request for Sex Reassignment Surgery," International Journal of Medical Toxicology and Forensic Medicine, vol. 2 (4): 128-134.

Al-Qaradawi, Y. (1999). The Lawful and the Prohibited in Islam (al-Halal wal Haram fil Islam). American Trust Publications.

Ali, Yusuf, trans. (2010). The Qur'an: Translation. 26th US edition, ed. S. Smith. New York. Tahrike Tarsile Qur'an, Inc. 
Anne Fausto-Sterling (1993). "The Five Sexes: Why Male and Female Are Not Enough." SCIENCES, vol. 20 (21), 255-286.

Bahreini, Raha (2008). "From Perversion to Pathology: Discourses and Practices of Gender Policing in the Islamic Republic of Iran," Muslim World Journal of Human Rights, vol. 5 (1), 1-49.

Bahreini, Raha (2012). "Human Rights Violations against Individuals of Diverse Sexual Orientations and Gender Identities in the Islamic Republic of Iran."

Bello, S. I. A. A. (2012). "The Punishment of Homosexuality in Islamic Contemporary World: Bello, Malaysia, Iran, Pakistan and Saudi Arabia As A Case Study," (2012).

Benjamin, H. (1999). The Transsexual Phenomenon. New York: The Julian Press, Inc.

Bolatito, LA (2013). "The Natural Law Theory of Morality and the Homosexuality Debate in an African Culture," OGIRISI: A New Journal of African Studies, vol. 9 (1).

Bucar Elizabeth M. (2010). "Bodies at the Margins: The Case of Transsexuality in Catholic and Shia Ethics," Journal of Religious Ethics, vol. 38 (4), 601-615.

Bucar, Elizabeth M. Enke, Anne (2011). "Unlikely Sex Change Capitals of the World: Trinidad, United States, and Tehran, Iran, as Twin Yardsticks of Homonormative Liberalism," Feminist Studies, vol. 37 (2), 301-328.

Bucar Elizabeth M. Shirazi, Faegheh (2012). “The 'Invention' of Lesbian Acts in Iran: Interpretative Moves, Hidden Assumptions, and Emerging Categories of Sexuality." Journal of Lesbian Studies, vol. 16 (4), 416434.

Coggon, John, Hammond, Natasha, Holm, Soren (2008). "Transsexuals in Sport-Fairness and Freedom, Regulation and Law," Sports Ethics and Philosophy, vol. 2 (1), 4-17.

Fathi, Nazila (2004). "As Repression Eases, More Iranians Change their Sex," New York Times, http://www.nytimes.com/2004/08/02/world/ as-repression-eases-more-iranians-change-theirsex.funded-sex-changesurgery.

Graham, David (2010). “Iran's Solution to 'Gay Problem', State-Funded Sex Change Surgery," Toronto Star, http:/www.thestar.com/living/ article/890223--Iran-s-solution-to-gay-problem state. 
Javaheri, Fatemeh (2010). "A Study of Transsexuality in Iran," Iranian Studies, vol. 43 (3), 365-377.

Kariminia Muhammad (2010). Taghir e jensiyat az manzare fiqh va hoghogh [Sex Change according to jurisprudence and law]. Entesharat e Markaz e Fiqhi A'emmeh e Athat [The Jurisprudential Press Center of the Imams]. Iran. Qum

Khomeini, Ruhullah (2000). "Tahrir Al- Wasila, Changing of Sex," vol. 2 (1) \& (2), 596-598. Qum. Mu'assasah Tanzim va Nashr Aasar Imam Khomeini. Reference (in German): http://islamic-centre-hamburg.de/alfadsch...90/af090_19.htm

Malik Ibn Anas (2001). "al-Muwatta", The First Formulation of Islamic Law, vol. 1, trans. Aisha Abdurrahman Bewley. Inverness, Scotland: Medina Press.

Najmabadi, Afsaneh (2005). Women with Mustaches and Men without Beards, Gender and Sexual Anxieties of Iranian Modernity. Berkeley: University of California Press.

Najmabadi, Afsaneh (2008). "Transing and Transpassing across Sex-Gender Walls in Iran," Women's Studies Quarterly, vol. 36 (3-4), 23-42.

Najmabadi,Afsaneh (2011). "Verdicts of Science, Ruling of Faith: Transgender/ Sexuality in Contemporary Iran," Social Research, vol. 78 (2), 533-556.

Najmabadi, Afsaneh (2012). Sex-in-Change: Configurations of Gender and Sexuality in Contemporary Iran. Durham, NC: Duke University Press.

Rehman, J. \& Polymenopoulou, E. (2012). "Is Green a part of the Rainbow? Sharia, Homosexuality and LGBT Rights in the Muslim World," Fordham International Law Journal, vol. 37 (1).

Tait, Robert (2005). "A Fatwa for Freedom," The Guardian World News Section. http://www.guardian.co.uk/world/2005/jul/27/gayrights.iran., accessed on 27 July 2005.

Tait, Robert (2007). "Sex Change Funding Undermines No Gays Claim," The Guardian. http://www.guardian.co.uk/world/2007/sep/26/iran.gender, accessed on 5 May 2008.

Sanders, Paula (1991). "Gendering the Ungendering Body: Hermaphrodite in Medieval Islamic Law," in Women in Middle Eastern History, ed. Nikki Keddie \& Beth Baron. New Haven and London: Yale University Press, 74-95.

Shakir (1979). Translation of the Qur'ān. Lahore, Pakistan: Raheel Publication. 
Shapiro, Judith (2008). "On the Persistence of Gender and the Mutability of Sex, Same-sex Cultures and Sexualities," An Anthropological Reader Journal, vol. 6.

Simon Rita, James \& Brooks, Alison (2009). "Gay and Lesbian Communities the World Over," Islam and Homosexuality. Social Science, vol. 13.

Hrdy, S. B., \& Symons, D. (1979). The Evolution of Human Sexuality: The Latest Word and the Last. New York: The University of Chicago Press 
Journal of Shariah Law Research (JSLR) 